\title{
Implementation of Training Programmes and Its Effect on Employee Performance in the Federal Road Safety Corps, Anambra State Sector Command, Nigeria
}

\author{
UGWUANYI, KENNETH EKENE \\ Department of Public Administration, \\ COOU/NAU, Anambra State, \\ Nigeria \\ ken4academic@yahoo.com
}

\author{
OMEJE, FIDEL NKECHI \\ Department of Public \\ Administration, COOU, Igbariam \\ Campus, Anambra State, \\ Nigeria
}

\author{
EMENIKE, EKENE \\ Department of Public \\ Administration, \\ Chukwuemeka Odumegwu Ojukwu \\ University, Igbariam Campus, \\ Anambra State, Nigeria
}

\author{
OKIAH-CHUKWUMA, EBELE. $P$ \\ Department of Public Administration \\ Chukwuemeka Odumegwu Ojukwu University \\ Igbariam Campus, Anambra State, \\ Nigeria
}

\author{
OBI, E. F \\ Department of Public Administration \\ Nnamdi Azikiwe University, \\ Awka. Anambra State, \\ Nigeria
}

\begin{abstract}
That training programmes are supposed to enhance employees' performance is an obvious fact in human resource management literature. Empirical observations however, have revealed that the implementation of training programmes, especially within the context of most public sector organizations, often leave much to be desired. To this end, this paper focuses on the implementation of training programmes in public sector organizations and how they affect employees' performance. Data for this research paper was obtained through secondary sources based on content analysis. The paper was anchored on Victor Vroom's Expectancy theory as a framework for our discussion. The argument of this paper is that the gap between the ideal situation and what is obtainable in practice, with respect to staff training is created at the stage of implementation. In view of this finding, the paper therefore recommends, among others, that training programs in public sector organizations should be implemented in such a way as to achieve SMART objectives in terms of the goals being Specific, Measurable, Achievable, Realistic and Time bound.
\end{abstract}

\section{Keywords}

Training, Performance, Organization, Human Resource

\section{INTRODUCTION}

For any organization to actualize its stated goal, training of employee of such organization must be prioritized. Every organizational set goal requires clearly defined training programmes to achieve such goal. As a matter of fact the level of versatility of an organization should reflect in equal measure with the designed training programme. It is obligatory to enhance the skill level and increase the resourcefulness and adoptability of employees. Training is the organized procedure By which people learn knowledge and/or skill for a definite purpose (Dale as cited by Babjohn, Tejaswani and Neema
2017) Emma (2013) stated that training is a learning process that involves the acquisition of skills by employees to enable them increases their performance. He went further to reveal that most organization does pay less attention to training of their employee with their reasons of maximizing profit which he summarized as acting in their own danger. Famibuyan (2001) as cited in ObiAnike and Ekwe (2014) defines training as the systematic process of altering the behaviour and or attitudes of employees in direction to increase organizational goals and development as programmes generally aimed at educating supervisory employees above and beyond the immediate technical requirement of the job and have a main objective of the improvement of the effective performance of all managers. Most organizations, especially public sector do engage in one form of training programme or the other for their employees but the greater challenge lies in the implementation of the outcome of such training programmes. Budgetary provision are made annually in most public organizations appropriation act for training programmes, yet the much expected outcome of such allocations are lacking. This is more worrisome especially when some public organization come out in the media to inform the general public of the success of their training programme and how the participant have decided to implement their communiqué only to be seen in their old order within a short while.

\section{CONCEPTUAL CLARIFICATION \\ 2.1 Training Programme}

Many scholars have argued in fevour of the high need for training programme in an organization. It is a very vital subject of discussion as is very fundamental to advancement in knowledge and attitudinal disposition of worker in organization. Training is adjourned to be rapidly advancing in personnel management (Ob-Anike and Ekwe, 2014). Ajakemo (2003) conceive training as a process which involves the acquisition of skills, concepts, rules or attitude in order to improve present and future performance. Accurate improvement of workers 
competent through teaching of new idea by a coach will definitely boost their output level. This will equally improve their employability level to both local and international markets economy of human capital. Training means the process of rising skills, routine, acquaintance and aptitudes of employees for the overall target of advancing the efficacy of employees in their positions both for present and future (Avasthi, 2006 as cited in Ogunbodede 2016) Methods of Training and Development Training and development has been classified under two main categories which are; on-the-job and off-the-job training. It must be noted that both on-the job training and off-the-job training are genre terminologies for classifications of training and development and not training and development methods proper. Organization could deliberately conduct training of their workers within with utmost reasons of saving cost and impacting of their culture on the employees especially newly recruited ones. On the other hand the organization could conduct their training within the organization using best available method to instill the organizational cum training programme's target to their trainees. Some of the training and development methods that may be co-opted by an organization to upgrade the skills of its employees include apprenticeships, induction and job rotation. On the other hand, employees could be trained outside their organization with other suitable methods. (Adeleye, Adegbite and Aderemi, 2014) Emma (2013:86) stated that human resource could be developed through scores of method viz: Orientation and induction, off-the job Training, refresher course, Management Seminars, Conferences and workshops, University-based training and University-based Part-time programme. The major purpose of employee training is to encourage readiness of employee performance in his assigned duties through enhance skill. Many organizations design their training programmes as it will suit their organizational environment but for training to be effective a systematic pattern must be adopted. Training programmes that lack varieties have greater chances of not meeting up with the expected outcome (Explorance, 2021). The following five vital steps to should be looked into while planning to create effective training programs that could both result in positive business impacts and support the drive for a comprehensive Experience Management strategy (Explorance, 2021).

a) Develop training needs: The very basic step in developing sustainable and impactful training program is to spot out performance deficiency to weigh the need for training.

b) Lay down organizations anticipated training Goal: Every organization ought to have clearly stipulated goals to achieve before embarking on any training arrangement. This could be to achieve skills on how to maximally utilize new technology in office and so on.

c) Map out training plans. It is advisable that training direction be unveiled at this level to control action of both the trainer and trainees. Material and pattern of such training need to be made visible at this level.

d) Implementation of the training action plans proper. This goes deeper into the physical manifestation of the behavioral disposition of workers in an organization in a patterned direction the employers desired.. This is critical for evaluation of the effectiveness of the action plans

e) Evaluate \& revise training: As mentioned in the last segment, the training program should be continually monitored will sole aim of evaluating either the success or failure of the program. (https://explorance.com/blog/5steps-to-creating-effective-training-programs/)

\subsection{Employee Performance}

An employed staff of any organization is expected to perform some functions which created gap for the recruitment in the first place. Zuheir (2018) postulated that performance incorporates the resulting outcomes of the performed actions of employees based on their expertise and skills Employee performance, according to Huselid, (1995) as cited in Aborampah (2015), is the enhancement of the knowledge, skills, and abilities acquired by employees so that they can perform their duties to achieve organizational goals. To ensure employees optimal performance in his or her work schedule, certain measures must be put in place to track the performance level. According to information in Profit.co blog site, performance assessment is very fundamental in assisting Human Resource (HR) department not only in identifying productivity level of employees, peculiar challenges of employees and training need. The following metric were captured;

a) Work Efficiency

b) Teamwork

c) Quality of work

d) Adherence to timelines

The following will be useful to evaluate the overall efficiency of an employee:

a) Choose the output or quantity, for example the number of tasks completed

b) Select a time period to measure, for example, during the course of a month

c) Measure the amount of output over your given time period. Look at the average for the workplace. This will give a benchmark to measure. The input value is the time the employee put in to get to output for example the number of hours.

d) Divide the output by the input to get a per-hour figure.

\subsection{Public Sector}

Public sector is vividly understood by greater section of the society for its services oriented anchored on welfare of the populace. The composition of the public sector varies by country, but in most countries the public sector includes such services as the military, police, Federal Road Safety Commission, public transit, ducation, roads, health sectors and those working for the government itself, such as elected officials and civil/public servant (Obasa 2018). It will be worthy to note that most public sectors are more concerned with service delivery to the citizens than profit making.

\section{THEORETICAL FRAMEWORK}

Victor Vroom Expectancy theory of Motivation 1964 This theory is of the view that man is deliberately careful of his decisions where there is alternative. It also assumes that man want to abstain from challenging task and enjoy more of pleasurable life. Attitude of people in their place of work is derived by some other things ranging from, understanding and level of awareness, skills and competences on the work. (Lawler, Porter and vroom 1964 as pulled from https://www.ifm.eng.cam.ac.uk/research/dstools/vroomsexpectancy-theory/) Expectancy theory is a strong believer that despite variation of individuals aims in an organization; they could be motivated. The theory centers it's believed on the following; 


\subsection{Valence}

This has to do people state of the mind over the like outcome of their input in an organization. Man constantly engages in intrapersonal query of his mind over long physical gains of his actions at any given. It is paramount for employers to look inward on what pushes their employees towards positive actions and maximize such discoveries Management must discover what employee's value.

\subsection{Expectancy}

As man is unique so his expectation in whatever he does which working life cannot be excluded. It is onus on his employer to inter-marry their workers personal expectations with that of the organizational wider goals.

\subsection{Instrumentality}

The final inner resolution of the mind of the worker as to the final attainment of there is brought to bear here. In federal road safety corps Anambra state sector command, the reality of instrumentality of this theory is farfetched as most Federal government of Nigeria promises to improve condition of welfare of employees of this sector could be best described as lip services.

(https://www.ifm.eng.cam.ac.uk/research/dstools/vroomsexpectancy-theory/)

The tenet of this theory should be taken into cognizance as the level of implementation of training programme in public sector could be affected by the employee's perception on Valence, Expectancy and Instrumentality features of Vrooms theory of motivation. This could be buttressed further by the fact that Nigeria's unemployment rate is forecasted at $32.5 \%$ for the year 2021 (www.statista.com) which resulted to most unemployed struggling to gain employment in any organization not minding if such organization could meet his or personal goal or not.

\section{IMPLEMENTATION OF TRAINING PROGRAMMES IN PUBLIC SECTOR ORGANIZATION IN NIGERIA: THEORY VS PRACTICE.}

Several training programmes have been conducted by various public sectors in Nigeria, but the questions in most persons mind is what happens to the implementations of such training outcome. For-instance federal road safety commission has been conducting different categories of training for her employee especially as it affects their official conduct with the road users. Many scholars have argued that the existence of obvious unethical behaviour in FRSC contradict with act establishing it. Ordinarily it is expected that FRSC should leave to the expectation of ethical standard captured in their establishment act of 2007 but reverse is the case here. (https://frsc.gov.ng/LCEP.pdf). Complying and abiding with professional ethical norms in every organization depends to an extent on individual's attitude toward these ethical norms despite the organization adopted strategy to checkmate deviants. Some opinion molders are of the view that non implementation of training programmes in public sector should be viewed from two perspectives. Employers and employees perspectives on valence, expectancy and instrumentality belief of Vroom expectancy theory of motivation. Employees emotional condition on the rewards that awaits him or her in the new training programme is a very big factor that must not be ignored, because where the employees saw new training programme as a mere policy document which the employer are not ready to implement to protect their workers interest, the employee may not have the drive to pursue its implementation vigorously. On the other hand some employees of public sector technically refuse to implement such training programme on the ground of fear of losing control. For-instance, FRSC has trained its personnel not to extort money from the motorist but its implementation is becoming resistant. Vanguard newspaper of August 24th 2019 confirmed the arrest of 37 FRSC personnel for alleged extortion of motorists on the highways. Corps Public Education Officer, Mr. Bisi Kazeem confirmed this ugly development and revealed further that the arrest were made in collaboration with Independent Corrupt Practices and other related offences commission (ICPC) and Department of State Service (DSS). He stated point blank that incident of extortion is very high in six states which are Kaduna, Bauchi, Abia, Rivers, Kogi and Ogun States.

(https://www.vanguardngr.com/2019/08/take-bribe-get-fired-

frsc-warns-personnel/)

FRSC have trained their employees not to pursue fleeing traffic offenders, this was confirmed by Sector Commander of Oyo State Uche Chukwurah as reported in Premium Times of 15th July 2021. He affirmed that detail all vehicles in Nigerian roads is domiciled in their data base. According to Vanguard News Paper of Apil 13th 2019, FRSC operatives continued to chase a commercial Micra Car until, it crashed and killing one person while four other passengers sustained critical injury. FRSC as one of the Government organization constitutionally empowered with the responsibility of Road Traffic Management in Nigeria has identified speeding as one causes engineering constant accident on our roads. Federal Road Safety Commission intends to implement and enforce the use of Speed Limiting devices in vehicles starting with commercial vehicles nationwide.

(https://speedlimiter.frsc.gov.ng/About-Speed-Limiting-Device) Boboye Oyeyemi, the Corps Marshal of the FRSC announced that the implementation of speed-limiting device on commercial vehicles in the country will start on 1st of October 2016. (https://www.premiumtimesng.com/news/more-news/208414speed-limiting-device-policy-begin-october-1-frsc.html) Anambra State Sector Commander of FRSC Adeoye Irelewuyi have stated unequivocally that speeding above limit is major causes of vehicle accident in Anambra State. This was revealed during the Sixth United Nations Global Road Safety Week (UNGRSW) press briefing. He on the other hand advocated for moderate 30 kilometer speed limit per hour within the towns with overall target of minimizing road rashes within the state (Vanguard newspaper of 17th May 2021).

\section{BRIEF HISTORY OF FEDERAL ROAD SAFETY CORPS}

The then military Government of Ibrahim Badamasu Babangida created the commission in 1988 and the civilian Government of Olusegun of Obasanjo ratified the military decree into civilian act of parliament of 2007. Prof Wole Soyinka is the first board chairman of the commission from 19988 to 1992.

\subsection{The Corps Vision}

Is to minimize road accident and maintain easy flow of traffic within Nigeria. (https://frsc.gov.ng/what-we-do/) 


\subsection{Mission Statement}

Regulations, coordination and enforcement of road traffic and safety management via Sustained public enlightenment, Promotion of stakeholder's cooperation, Robust data management Improved vehicle administration Prompt rescue services $\quad$ Effective patrol operation (https://frsc.gov.ng/what-we-do/)

\section{RECOMMENDATION AND WAY FORWARD}

This paper is recommending that public sector organization should be very serious with the implementation of the outcome of any training programme conducted. Federal Road Safety Corps should institute a unit like non uniform group that could independently monitor the implementation of their training programmes by their officer on road. By so doing the gap of low production in public sector organization will be bridged and goals being achieved in Specific, Measurable, Achievable, Realistic and Time bound (SMART) mechanism.

\section{CONCLUSION}

This study concludes that all trainings conducted by federal road safety corps Anambra State sector Command, Nigeria should be implemented timely. This is to justify the approved fund and other logistics spent on such training programmes. It will also go a long way in reducing road crashes emanating as a result of non-implementation of such training programmes and safe lives.

\section{REFERENCES}

[1] Ogunbodede, N. (201) In Service Training and Job Satisfaction in the Nigerian Public Service: A Theoretical Analysis. International Journal of Academic Research in Business and Social Sciences. Vol.6 (5). DOI: 10.6007/IJARBSS/v6-i5/2122

[2] Babjohn, D. Tejaswani, R and Neema, K. 2017. Over View of Training \& Development. International Journal of science and management.vol. 6(01).

[3] Emma,.C. 2011 .The substance of public administration in Nigeria (A Compendlum):Enugu, Pofessors's Press.

[4] H.O. Obi-Anike, and M.C. Ekwe, 2014. Impact of Training and Development on organizational Effectiveness: Evidence from selected public sector organization in Nigeria.European Journal of Business and management. Vol.6 (29)

[5] Stephen, O.O. 2018. Challenges and Strategies for Improving Public Sector Performance in Nigeria: Global Scientific Journal. Vol.6 (11).

[6] T.S. 2017 Training Development and performance of Nigerian Educational Sector: Asia International multi disciplinary conference

[7] Zuheir, M.,D. 2008. The Determinants of employee Performance DOI:10.17261/Pressacademic.2018.780

[8] https://frsc.gov.ng/what-we-do/

[9] https://www.profit.co/blog/performance-management/top-5employee-performance-metrics-you-must-track/

[10] https://www.ifm.eng.cam.ac.uk/research/dstools/vroomsexpectancy-theory/

[11] https://www.statista.com/statistics/1119227/forecastedunemployment-rate-in-nigeria/
[12] https://www.vanguardngr.com/2019/08/take-bribe-getfired-frsc-warns-personnel/

[13] https://explorance.com/blog/5-steps-to-creating-effectivetraining-programs/

[14] https://www.statista.com/statistics/1119227/forcastedunemployment-rate-in-nigeria/

[15] https://www.premiumtimesng.com/regional/ssouthwest/473825-why-we-no-longer-pursue-fleeing-trafficoffenders-frsc.html

[16] https://www.vanguardngr.com/2021/05/speeding-abovelimit-major-cause-of-accidents-in-anambra-frsc/

[17] https://speedlimiter.frsc.gov.ng/About-Speed-LimitingDevice

[18] https://www.yourarticlelibrary.com/human-resourcedevelopment/training-meaning-definition-and-types-oftraining/32374

[19] https://www.coursehero.com/file/p6dvasfb/On-the-Joband-Off-the-Job-Adeleye-Adegbite-and-Aderemi-2014-hav e-classified/ 